\title{
Superior Medullary Velum: Anatomical-Histological Study in the Sheep Brain and a Preliminary Tractographic Study in the Human Brain
}

\author{
Süperior Meduller Velum: Koyun Beyninde Anatomik-Histolojik Çalışma \\ ve Insan Beyninde Ön Traktografik Çalusma
}

\author{
Nuriye Guzin OZDEMIR ${ }^{1}$, Merih IS ${ }^{2}$, Süheyla Uyar BOZKURT ${ }^{3}$, Kaya KILIC ${ }^{1}$, Askin SEKER ${ }^{4}$ \\ ${ }_{1}^{1}$ Istanbul Training and Research Hospital, Neurosurgery Clinic, Istanbul, Turkey \\ ${ }^{2}$ Fatih Sultan Mehmet Training and Research Hospital, Neurosurgery Clinic, Istanbul, Turkey \\ ${ }_{3}^{3}$ Marmara University Training and Research Hospital, Department of Pathology, Istanbul, Turkey \\ ${ }^{4}$ Training and Research Hospital, Department of Neurosurgery, Istanbul, Turkey
}

Corresponding Author: Nuriye Guzin OZDEMIR / E-mail: guzozdemir@yahoo.com

\begin{abstract}
AIM: To study the anatomy, histology and fiber relations of the superior medullary velum.

MATERIAL and METHODS: Ten previously frozen and formalin-fixed sheep brains were used. The fiber dissection was done using the operating microscope at the Rhoton Anatomy Laboratory of Marmara Faculty of Medicine. A tractographic study was conducted on five volunteer patients to see the fiber anatomy of the superior medullary velum.

RESULTS: The average thickness and length was found to be $0.296 \mathrm{~mm}$ (range $0.09-1 \mathrm{~mm}$ ) and $4.25 \mathrm{~mm}$ (range $3.25-4.5 \mathrm{~mm}$ ) respectively. Histologically, the superior medullary velum consisted of cuboidal layer of ependymal cells on the anterior surface related to fourth ventricle. The subependymal layer contained hypocellular fibrillary zone with few glial cells, and the outer layer consisted of thin layer of fibroblasts. Under the hypocellular fibrillary zone, abundant axons and organized structures were observed. Tractographically, only a few fibers were identified on diffusion-tensor imaging (DTI).

CONCLUSION: We could not identify a distinct tract anatomically and neuron cells histologically. Neuron-like cells and organized structures were observed on immunohistochemical analysis. Also a few tracts were observed on DTI study as an ascending pathway from spinal tracts to the superior medullary velum. Further studies including human cadaveric, histologic and fiber tractographic investigations are needed to say that it is harmless to divide this anatomical structure.
\end{abstract}

KEYWORDS: Anatomy, Fiber dissection, Histology, Sheep, Superior medullary velum, Tractography

öz

AMAÇ: Süperior medüller velumun anatomi, histolojisi ve lif bağlantılarını çalışmak.

YÖNTEM ve GEREÇLER: Önceden formalinle fikse edilerek dondurulmuş 10 adet koyun beyni kullanıldı. Fiber diseksiyon, Marmara Nörolojik Bilimler Enstitüsü Rhoton Anatomi Laboratuvarı'nda yapıldı. Ayrıca 5 gönüllü hastada süperior medüller velumun lif bağlantılarını görmek için traktografi yapıldı.

BULGULAR: Ortalama kalınlık ve uzunluk sırasıyla 0,296 mm (aralık 0,09-1 mm) ve 4,25 mm (aralık 3,25-4,5 mm) olarak bulundu. Histolojik olarak süperior medüller velumun 4. ventriküle bakan anterior yüzünde ependimal küboidal hücreler gözlendi. Subependimal tabakada birkaç glial hücreyle birlikte hiposellüler fibriler bölge, dış ince tabakada ise fibroblastlar görüldü. Hiposellüler fibriler bölgenin altında bol miktarda akson ve organize yapılar görülmekle birlikte, nöron spesifik boyalarla sadece birkaç nöron benzeri yapı dışında nöron gözlenmedi. Difüzyon tensör görüntülemede (DTG) sadece birkaç trakt izlendi.

SONUÇ: Anatomik olarak belirgin bir trakt ve histolojik olarak nöronal yapı tanımlanamadı. İmmünohistokimyasal olarak sadece nöronbenzeri hücreler ve organize yapılar gözlendi. DTG çalışmasında spinal kord'dan süperior medüller velum'a çıkan birkaç trakt izlenebildi. Bu yapıyı cerrahi yaklaşımlarda trakt ve nöronlara zarar vermeden feda edebiliyoruz diyebilmek için daha çok sayıda insan kadavra, histoloji ve traktografi de içeren ileri araştırmaya ihtiyaç vardır.

ANAHTAR SÖZCÜKLER: Anatomi, Fiber diseksiyon, Histoloji, Koyun, Süperior medüller velum, Traktografi 


\section{INTRODUCTION}

The superior medullary velum is a thin lamina of white matter extending between the superior cerebellar peduncles. It forms a part of the roof the fourth ventricle. On either side of the fourth ventricle the roof is pushed out over the restiform body forming the lateral recesses. The choroid plexus of the fourth ventricle invaginates into the epithelium of the roof and is suspended from the inferior medullary velum (18).

On the dorsal surface of the lower half of the superior medullary velum the folia and lingula are prolonged. The frenulum veli exists on its upper part and under the inferior colliculi where the trochlear nerve emerges on both sides. Its blood supply is from the superior cerebellar artery $(18,28)$.

To our knowledge there is only one study about the anatomy of the inferior medullary velum, but except from the morphometric, clinical and radiological studies, there are no reports relevant to the anatomy of the superior medullary velum. As classical anatomy knowledge, Rhoton has described that this structure forms the upper part of the roof of the fourth ventricle and the lingula lies over it $(9,15$, $18,20,26,27,30)$.

There are superior and inferior laminae arising from the medullary body embryologically. These medullary vela are thin laminae composed of white substance (19). Also there are literature reports suggesting the presence of neurons, especially related to the trochlear nerve and the mesencephalic nucleus of the trigeminal nerve in the superior medullary velum $(21,23)$.

The telovelar approach to the fourth ventricle, traversing the inferior medullary velum, has been used as a safe technique for posterior fossa lesions, and division of the inferior medullary velum has been shown to be harmless as no neuronal cells were identified in this structure $(18,27)$. The superior medullary velum has been sacrificed in trapped fourth ventricle hydrocephalus cases (19). Whether it is safe to cut this structure without any complication is a question that needs to be answered. This study was performed to obtain information about the anatomy and histology of the superior medullary velum since there are few mentions in the literature.

\section{MATERIAL and METHODS}

Ten sheep formalin-fixed brains were used in this study. Craniectomy was done to evacuate the brains for the first 5 heads. Since the occipital region of the sheep was too thick and did not allow total dissection of the posterior region in a smooth fashion, craniotomy was done for the latter 5 heads with the help of the craniotome. The specimens were fixed in $10 \%$ formalin solution for 3 weeks. Then dura and microvascular structures were dissected, and again fixed for 4 weeks at $-20^{\circ} \mathrm{C}$, after which the dissection began.

All the anatomical and immunohistochemical studies were done at the Marmara University Neurological Sciences Institute's Rhoton Anatomy Laboratory and the Institute's histological laboratory respectively. The dissections were done in an order as dorsal, lateral, medial, anterior, ventral and posterior dissection using Klingler's method. Five specimens were excluded from the study since fixations were not good enough to dissect the structures. These were the brains in which craniectomy was done alone without using craniotomy. The cerebellum was removed with the tectum and tegmentum, Gross observations and measurements were performed on both sagittal and posterior sections. The superior medullary velum was observed under the operating microscope with X0.6 and X1 magnifications. Then $2 \mathrm{~mm}$ sagittal slices were taken for the immunohistochemical analyses.

For the radiological study, five volunteer patients underwent tractographic evaluation to investigate the upper and lower fiber tract pathway of the superior medullary velum. Brain MRI was performed on a whole-body 1.5-T scanner (1.5-T, Siemens Magnetom, Espree, Germany) with an eight-channel head coil. Diffusion-tensor imaging (DTI) was performed using a single-shot multi-slice spin echo-echo planar sequence.

This study was approved by the ethics committee of Marmara University Neurological Sciences Institute and informed written consent was taken from the patients undergoing tractography.

\section{RESULTS}

Gross anatomically, two superior medullary vela blend in the middle under the inferior colliculi posteriorly on both sides. The frenulum could not be observed in the sheep brain as distinctly as seen in human cadavers. Sagittally, the superior medullary velum forms part of the roof of the fourth ventricle and as it descends to the cerebellum it blends with the superior cerebellar peduncle. The lingula lies over it (Figure $1 ; 2 \mathrm{~A}, \mathrm{~B})$.

The average thickness of the superior medullary velum was found to be $0.296 \mathrm{~mm}$ (range $0.09-1 \mathrm{~mm}$ ), and the average length was found to be $4.25 \mathrm{~mm}$ (range 3.25-4.5 mm).

Histologically, the superior medullary velum consisted of a cuboidal layer of ependymal cells on the anterior surface related to the fourth ventricle. The subependymal layer contained a hypocellular fibrillary zone with few glial cells, and the outer layer consisted of thin layer of fibroblasts. Under the hypocellular fibrillary zone, abundant axons and organized structures were observed. With neuron-specific stains, no neurons, but only few neuron-like cells were identified (Figure 3).

Tractographically, on sagittal sections, only a few fibers could be followed ascending from the spinal tracts on both sides which could be named as the anterior spinocerebellar tract, entering the superior cerebellar peduncle via the superior medullary velum; however we could not observe any tracts on axial DTI images.

\section{DISCUSSION}

The superior medullary velum is a thin lamina of white matter 


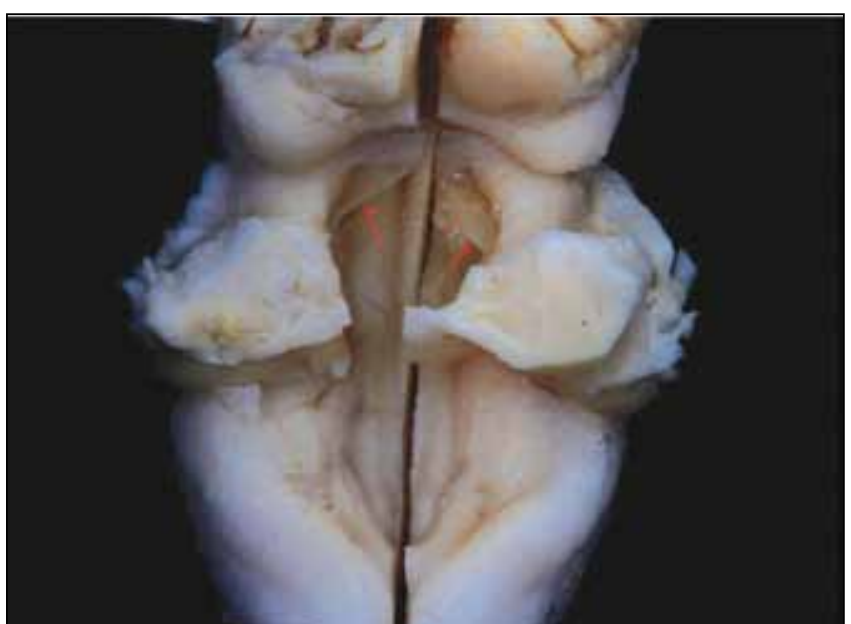

Figure 1: Superior medullary velum is seen on the posterior side after removal of the cerebellum (red arrows).
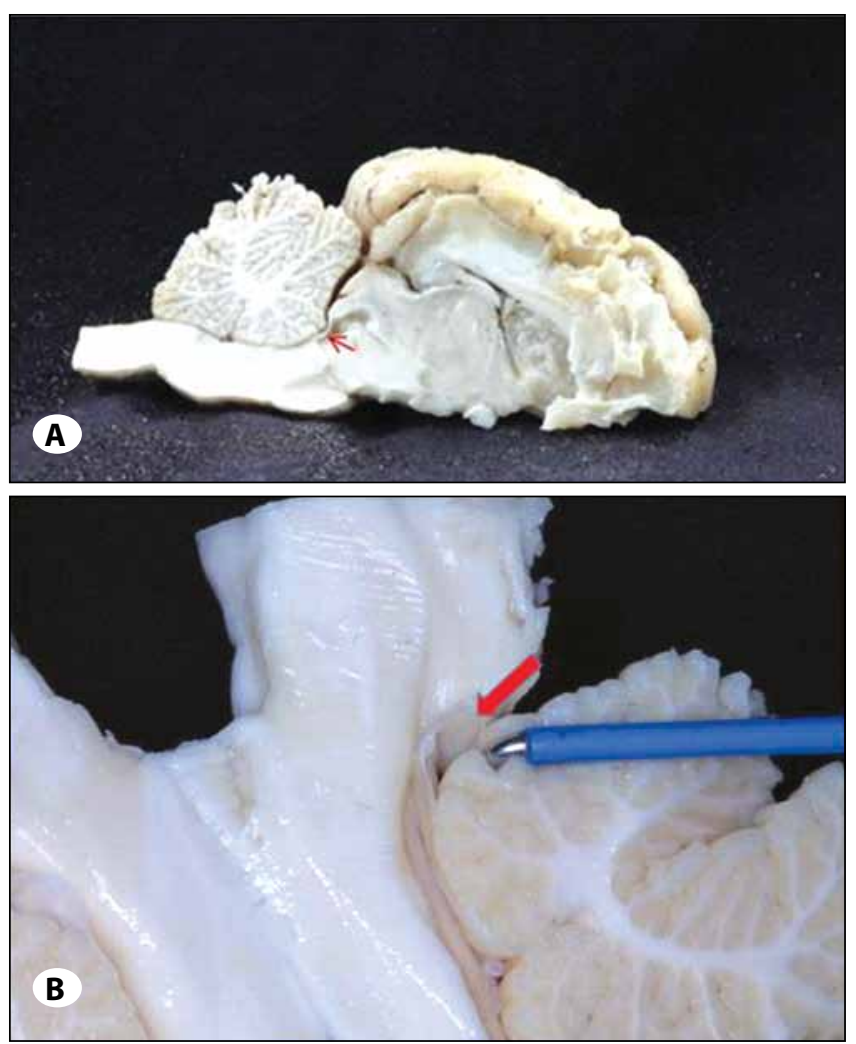

Figure 2: A) Superior medullary velum is seen on the sagittal section. B) Retracting the lingula by probe, the superior medullary velum is seen (thick red arrow).

stretching between the superior cerebellar peduncles. It forms the superior half of the roof of the fourth ventricle, together with the lingula and cerebellar peduncles. Embryologically it forms the rostral part of the cerebellum and arises from the alar plate of the isthmic segment $(15,19)$. Our gross anatomical finding is in agreement with the classical anatomical knowledge.
There are reports related to obstructive hydrocephalus in which the rostral portion of the superior medullary velum might be the origin of ventricular diverticula from the superior portion of the fourth ventricle (1). Regeneration of axons into the trochlear rootlet after anterior medullary lesions and regeneration of nerve fibers in the anterior medullary velum has been shown in experimental studies (5). The trochlear nerve nucleus is reported to originate from the superior medullary velum region. Bilateral superior oblique palsies are seen occasionally in hydrocephalus and the possible location is reported to be the superior medullary velum where the two nerves are crossed $(3,5,10,11,16,17,24,30)$. We could not observe the trochlear nerve anatomically or histologically in our study.

Vascularization of the superior medullary velum with the interpeduncular fossa, cerebral peduncle, midbrain, cerebellar cortex, inferior colliculus, lingula and vermis is reported to be from the vermian artery originating from the posterior cerebral artery (25). We did not study the vascular anatomy and only fiber dissection and immunohistochemical analysis were performed.

Early immunohistochemical studies about oligodendroglia showed that the glial precursors migrated to their final position in the cerebellum via the superior medullary velum (22). Mesencephalic trigeminal neurons were reported to be present in the anterior medullary velum in a study in which retrograde and transganglionic transport of horseradish peroxidase was used to show the central projections of mesencephalic trigeminal neurons innervating rat masticatory muscles (21). The mesencephalic trigeminal nucleus was also reported to be located on both sides of the mesencephalic tract, mingled with cells of locus coeruleus and in the superior medullary velum (23). In our histological study, no neurons were observed.

As classical anatomical knowledge, the anterior spinocerebellar tract ascends and enters the superior cerebellar peduncle via the superior medullary velum. Recently, a study about the paths, elongation, and projections of ascending spinal commissural neurons showed the axons entering the superior medullary velum (2). The anterior spinocerebellar tract is important in conveying proprioceptive and extroceptive information. Tractographically, few fibers ascending from the spinal cord were observed on sagittal images that could not be followed on axial sections. However, we could not observe any tracts but observed tract-like organizations immunohistologically. The immunohistochemical analysis was done with dyes appropriate for human tissue, which may have affected the results.

Blake's pouch cyst, defined as an entity within the DandyWalker malformation, is described as a posterior ballooning of the superior medullary velum into the cisterna magna. Superior medullary velum synechia together with aqueductal web, periaqueductal and tectal hamartomas are reported in neurofibromatosis type 1 patients with hydrocephalus. Fenestration of the superior medullary velum in the fourth 


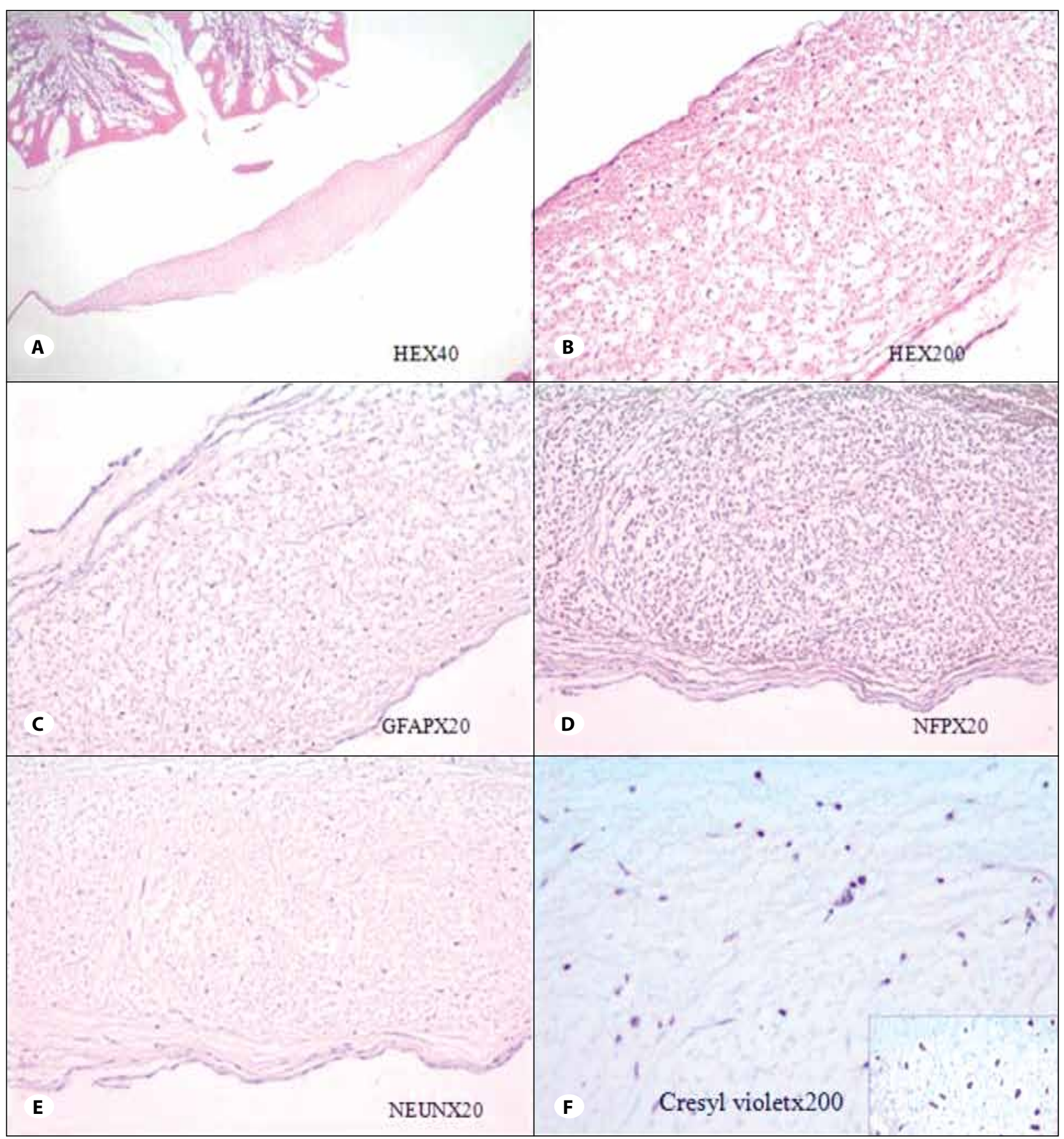

Figure 3: : Histological images: A) Cerebellar folia are seen on the upper side of the section, white matter structure attaching to the superior medullary velum with tiny bridges is seen (H\&EX40). B) White matter is seen with glial cells inside. On the inner side organized structure with axons and glial cells are seen intermittently, no neurons are observed. Cuboidal ependymal cells are seen on the lower side (H\&EX200). C) GFAPX20: Thin hypocellular fibrillary zone, scattered glial cells, fibroblastic cells on the outer layer and axons are seen in the central region. D) NFPX 20: Abundant axons are seen in the central region. E) NEUNX 20: Abundant axons and tract tractlike organized structures are observed. F) CRESYL VIOLETX200: Small arrows show few neuron-like cells, in the subset at the right bottom neuronal cells are seen to compare. 
ventricle as treatment is reported $(4,6,29)$. These reports do not state whether it is safe to fenestrate the superior medullary velum, without harming any neurons or tracts. In our study we could not show any neurons, but tract-like structures were observed. Due to these tract-like organizations, we cannot say that it is harmless to incise this structure.

Functionally, the superior medullary velum has been shown to be a part of the subarachnoid system and the CSF within the velae empty into the quadrigeminal and ambient cisterns (7).

In a clinical study, the superior medullary velum was reported to be the superior border in the occipital transtentorial keyhole approach (14). In the superior medullary velum region, lipomas are usually observed $(8,9)$.

The superior medullary velum can be secondarily invaded by a tumor from the cerebellum or quadrigeminal plate. Glial precursors may locate and give rise to a neoplastic lesion (22). We found few glial and neuron-like cells in the immunohistochemical evaluation and these cells may give rise to neoplastic changes.

Clinical and radiological features of tumors primarily arising from the superior medullary velum during childhood is discussed in the literature although it has not been previously described as the primary location of a posterior fossa tumor. The pathological diagnosis of all neoplasms was teratoid/ rhabdoid tumor (26). A large cell anaplastic T-cell lymphoma positive for Ki-antigen has also been reported (12).

Displacement of the quadrigeminal plate and especially superior displacement of the superior medullary velum in tumors of the fourth ventricle is observed in clinical studies. The position of the superior medullary velum as a diagnostic sign in the midline medulloblastoma versus astrocytoma cases in which the superior medullary velum is superiorly dislocated in the medulloblastomas, and anteriorly and/or inferiorly dislocated in the astrocytomas $(20,27)$.

The inferior medullary velum is used in the telovelar approach to fourth ventricle tumors without incising or removing part of the cerebellum. One study reported that there are no neurons or important structures in the inferior medullary velum and that it represents the remains of the cortical continuity between the flocculus and the nodule of the cerebellum, and can therefore be incised safely $(13,18,28)$.

\section{CONCLUSION}

According to our anatomical and immunohistochemical findings, there are organized structures rather than tracts and neuron-like cells rather than neurons in the superior medullary velum. Tractographically, there were only few fibers observed on sagittal sections. On axial and coronal sections, we could not find a followed tract.

This study was conducted on sheep brain and a limited number of volunteer patients for the tractographic study. An anatomical human cadaveric study supported by a larger number of human tractographic specimens is necessary to conclude that there are no tracts and neurons in the superior medullary velum, and to do operations in this region safely.

\section{REFERENCES}

1. Abe M, Uchino A, Tsuji T, Tabuchi K: Ventricular diverticula in obstructive hydrocephalus secondary to tumor growth. Neurosurgery 52:65-70, 2003

2. Arakawa $T$, Iwashita $M$, Matsuzaki $F$, Suzuki T, Yamamato $\mathrm{T}$ : Paths, elongation, and projections of ascending chick embryonic spinal commissural neurons after crossing the flor plate. Brain Res 5:1123-1125, 2008

3. Barr DB, McFadzean RM, Hadley D, Ramsay A, Houston CA, Russell D: Acquired bilateral superior oblique palsy: $A$ localising sign in the dorsal midbrain. Eur J Ophthalmol 7(3):271-276, 1997

4. Calabro F, Arcuri T, Jinkins JR: Blake's pouch cyst: An entity within the Dandy-Walker continuum. Neuroradiology 42: 290-295, 2000

5. Derouiche A, Berry M, Sievers J: Regeneration of axons into the trochlear rootlet after anterior medullary lesions in the rat is specific for ipsilateral IVth nerve motoneurones. J Comp Neurol 341:340-350, 1994

6. Dinçer A, Yener U, Özek MM: Hydrocephalus in patients with neurofibromatosis type 1: MR imaging findings and the outcome of endoscopic third ventriculostomy. AJNR 32:6436, 2011

7. Fenstermacher JD, Ghersi-Egea JF, Finnegan W, Chen JL: The rapid flow of cerebrospinal fluid from ventricles to cisterns via subarachnoid velae in the normal rat. Acta Neurochir Suppl 70:285-287, 1997

8. Friedman RB, Segal R, Latchaw RE: Computerized tomographic and magnetic resonance imaging of intracranial lipoma. Case report. J Neurosurg 65:407-410, 1986

9. Gouvea VM, Hahn MD, Chimelli L: Lipoma of the midbrain. Post-mortem finding in a patient with breast cancer. Arq Neuropsiquiatr 47:371-374, 1989

10. Guy JR, Friedman WF, Mickle JP: Bilateral trochlear nerve paresis in hydrocephalus. J Clin Neuroophthalmol 9:105-111, 1989

11. Hutchinson SP, McConnell P: Regeneration of nerve fibres in the anterior medullary velum of neonatal and weanling rats. Neuropathol Appl Neurobiol 16:69-83, 1990

12. Kawamura $T$, Inamura $T$, Ikezaki $K$, Miyazono $M$, Ishihara $\mathrm{S}$, Fukui M: Primary Ki-1 lymphoma in the central nervous system. J Clin Neurosci 8:574-577, 2001

13. Lister JR, Rhoton AL, Matsushima T, Peace DA: Microsurgical anatomy of the posterior inferior cerebellar artery. Neurosurgery 10:170-199, 1982

14. Ma Y, Lan Q: An anatomic study of the occipital transtentorial keyhole approach. World Neurosurg 80(1-2):183-189, 2013

15. Matsushima T, Rhoton AL, Lenkey C: Microsurgery of the fourth ventricle: Part 1. Microsurgical anatomy. Neurosurgery $11: 631-667,1982$ 
16. McConnell $P$, Berry $M$, Rees EL, Sievers J: The injury response of nerve fibers in the anterior medullary velum of the adult rat. Brain Res 323:257-268, 1984

17. Murphy EH, Garone M, Tashayyod D, Baker RB: Innervation of extraocular muscles in the rabbit. J Comp Neurol 254:78-90, 1986

18. Mussi AC, Rhoton AL Jr: Telovelar approach to the fourth ventricle: Microsurgical anatomy. J Neurosurg 92:812-823, 2000

19. Müller F, O'Rahilly R: The development of the human brain, including the longitudinal zoning in the diencephalon at stage 15. Anat Embryol 179:55-71, 1988

20. Nemoto $Y$, Inoue $Y$, Fukuda $T$, Shakudo $M$, Matsumura Y, Takemoto K, Oda J, Yahata S, Hakuba A, Nishimura S: Displacement of the quadrigeminal plate in tumors of the fourth ventricle: MR appearance. J Comput Assist Tomogr 13:769-772, 1989

21. Raappana P, Arvidsson J: Location, morphology, and central projections of mesencephalic trigeminal neurons innervating rat masticatory muscles studied by axonal transport of choleragenoid-horseradish peroxidase. J Comp Neurol 328:103-114, 1993

22. Reynolds R, Wilkin GP: Development of macroglial cells in rat cerebellum. II. An in situ immunohistochemical study of oligodendroglial lineage from precursor to mature myelinating cell. Development 102:409-425, 1988
23. Roşca T, Repciuc E: The mesencephalic nucleus of the trigeminus in man. Morphol Embryol 27:3-6, 1981

24. Saygı S, Atabay C, Kansu T, Ozcan OE: Hidrosefaliye bağlı bilateral IV. sinir parezisi: Vaka Takdimi. Türk Nöroşirürji Dergisi 2:158-160, 1991

25. Serarslan Y, Uluc K, Baskaya MK: A vermian artery originating from the posterior cerebral artery: An anatomical case report. Surg Radiol Anat 31:645-647, 2009

26. Tomita T, Frassanito P:Tumors of the superior medullary velum in infancy and childhood: Report of 6 cases. J Neurosurg Pediatr 11: 52-59, 2013

27. Trasimeni G, Lenzi J, Biasi CD, Anichini G, Salvati M, Raco A: Midline medulloblastoma versus astrocytoma: The position of the superior medullary velum as a sign for diagnosis. Childs Nerv Syst 24:1037-1041, 2008

28. Tubbs RS, Bosmia AN, Loukas M, Hattar EM, Cohen-Gadol AA: The inferior medullary velum: Anatomical study and neurosurgical relevance. J Neurosurg 118:315-318, 2013

29. Tubbs RS, Wellons JC 3rd, Salter G, Oakes WJ: Fenestration of the superior medullary velum as treatment for a trappde fourth ventricle: A feasibility study. Clin Anat 17:82-87, 2004

30. Yamaguchi K, Honma K: Development of the human trochlear nucleus: A morphometric study. Ann Anat 193:106-111, 2011 